\title{
PRODUCTION, CHARACTERIZATION AND USAGE OF A NOVEL DISULFONIC ACID-FUNCTIONALIZED IONIC LIQUID AS A HIGHLY EFFICIENT AND DUAL-FUNCTIONAL CATALYST FOR THE SYNTHESIS OF 1,8-DIOXO-9,10-DIARYL-DECAHYDROACRIDINES
}

\author{
Mostafa Karami and Abdolkarim Zare*,\# \\ Department of Chemistry, Payame Noor University, PO Box 19395-3697, Tehran, Iran
}

Recebido em 04/03/2018; aceito em 12/04/2018; publicado na web em 07/06/2018

\begin{abstract}
We have produced a novel ionic liquid $\left\{\mathrm{N}, \mathrm{N}, \mathrm{N}^{\prime}, \mathrm{N}^{\prime}\right.$-tetramethylethylene-diaminium-N,N'-disulfonic acid trifluoroacetate ([TMEDSA] $\left.\left.[\mathrm{TFA}]_{2}\right)\right\}$, and identified it by analysis of ${ }^{1} \mathrm{H}$ NMR, ${ }^{13} \mathrm{C}$ NMR, ${ }^{19} \mathrm{~F}$ NMR, mass, TG (thermogravimetry) and DSC (differential scanning calorimetry) data. Then, we have applied [TMEDSA][TFA $]_{2}$ as a dual-functional catalyst for the production of 1,8-dioxo-9,10-diaryldecahydroacridines by the multi-component reaction of dimedone with arylaldehydes and primary amines. Furthermore, we have proposed a plausible and attractive mechanism based on dual-functionality of the catalyst. Due to dual-functionality of [TMEDSA] $[\mathrm{TFA}]_{2}$ (possessing acidic and basic sites), and also possessing two sites of each, it was highly effective and general, and produced the products in high yields.
\end{abstract}

Keywords: N,N,N',N'-tetramethylethylene-diaminium-N,N'-disulfonic acid trifluoroacetate ([TMEDSA][TFA $\left.]_{2}\right)$; ionic liquid; dualfunctional catalyst; 1,8-dioxo-9,10-diaryl-decahydroacridine; multi-component reaction.

\section{INTRODUCTION}

Acridine derivatives are of importance as they have a variety of medicinal properties, such as anticancer, anti-multidrugresistant, antifungal, antimicrobial and cytoxic activities. ${ }^{1-5}$ These compounds are also utilized as photoinitiators and laser dyes. ${ }^{6,7}$ The practical method for production of 1,8-dioxo-9,10-diaryldecahydroacridines, as a significant class of acridine derivatives, is the multi-component condensation of arylaldehydes with dimedone and primary amines (or ammonium acetate) in the presence of a catalyst, e.g. nano- $\mathrm{ZrO}_{2}-\mathrm{SO}_{3} \mathrm{H},{ }^{8} \mathrm{Fe}_{3} \mathrm{O}_{4} @ \mathrm{SiO}_{2}-\mathrm{MoO}_{3} \mathrm{H}$ nanoparticles, ${ }^{9}$ imidazolium salts containing perfluoroalkyl tails, ${ }^{10}$ tungstophosphoric acid nanoparticles supported on polyamic acid, ${ }^{11}$ nano- $\mathrm{Fe}_{3} \mathrm{O}_{4},{ }^{12} \beta$-cyclodextrin, ${ }^{13} \mathrm{Fe}_{2} \mathrm{O}_{3}-\mathrm{ZrO}_{2},{ }^{14}$ nano- $\mathrm{TiO}_{2},{ }^{15}$ and sulfonated polyethylene glycol. ${ }^{16}$ Many of the reported methods for the production of 1,8-dioxo-9,10-diaryl-decahydroacridines suffer from one or more drawbacks consisting of moderate yield, long reaction time, high reaction temperature, difficulty in catalyst preparation, utilization of toxic solvents as reaction media, and application of expensive or toxic catalysts. So, it is desirable to introduce a novel catalyst for the synthesis of these heterocycles which overcome the above drawbacks.

Recently, ionic liquids have been widely applied as effective catalysts for organic transformations. ${ }^{17-24}$ These catalysts have many special physical and chemical properties, consisting of wide liquid temperature range, negligible vapor pressure, tunable hydrophobicity, good ionic conductivity, controlled miscibility, unique electrochemical properties, high thermal and chemical stability, and capability for catalyzing diverse kinds of organic reactions. ${ }^{17-24}$

One-pot multi-component reactions are of increasing importance in organic synthesis, since they can produce aim products in one step without isolating the intermediates, and consequently decrease reaction time, save energy and time, increase yield, reduce generating side-products, and minimize application of volatile organic solvents. ${ }^{25-27}$

*e-mail: abdolkarimzare@pnu.ac.ir

\#alternative e-mail: abdolkarimzare@yahoo.com
To develop our preceding studies on the preparation of ionic liquids, and their applications as catalysts in organic synthesis, ${ }^{21-24}$ we report here production of a novel ionic liquid bearing two acidic and two basic sites, i.e. $N, N, N^{\prime}, N^{\prime}$-tetramethylethylene-diaminium$N, N^{\prime}$-disulfonic acid trifluoroacetate ([TMEDSA][TFA $]_{2}$ ), and its identification by analysis of ${ }^{1} \mathrm{H}$ NMR, ${ }^{13} \mathrm{C}$ NMR, ${ }^{19} \mathrm{~F}$ NMR, mass, thermogravimetry (TG) and DSC (differential scanning calorimetry) data. Subsequently, we introduce [TMEDSA][TFA $]_{2}$ as a highly efficient, general and dual-functional catalyst to promote the preparation of 1,8-dioxo-9,10-diaryl-decahydroacridines via the reaction of dimedone, arylaldehydes and primary amines. It is noteworthy that our protocol has none of the above-mentioned drawbacks at all.

\section{EXPERIMENTAL}

\section{General}

The reactants and solvents were bought from Merck, Fluka or Acros Chemical Companies. Identification of the known compounds was accomplished by comparing their melting points and spectroscopic data with the reported ones. Monitoring progress of the reactions was achieved by thin layer chromatography (TLC). Recording the melting points was performed using a Büchi B-545 device in open capillary tubes. Spectra were recorded on the following devices: ${ }^{1} \mathrm{H}$ NMR (500 MHz), ${ }^{13} \mathrm{C}$ NMR (125.7 MHz) and ${ }^{19} \mathrm{~F}$ NMR (235 MHz) on Bruker Avance DPX, FT-NMR spectrometer; and mass spectra on spectrometer 5975C VL MSD model Tripe-Axis Detector.

\section{Preparation of $[$ TMEDSA $][\text { TFA }]_{2}$}

A solution of $N, N, N^{\prime}, N$ '-tetramethylethylene-diamine (5 mmol, $0.581 \mathrm{~g})$ in dry $\mathrm{CH}_{2} \mathrm{Cl}_{2}(30 \mathrm{~mL})$ was added dropwise to a stirring solution of chlorosulfonic acid (10 mmol, $1.165 \mathrm{~g})$ in dry $\mathrm{CH}_{2} \mathrm{Cl}_{2}$ $\left(30 \mathrm{~mL}\right.$ ) over a period of $10 \mathrm{~min}$, at $10{ }^{\circ} \mathrm{C}$. After that, the reaction mixture was allowed to heat to room temperature (accompanied with stirring), and stirred for another 4 hours. The solvent was evaporated under reduced pressure, and the liquid residue was triturated with dry 
petroleum ether $(3 \times 2 \mathrm{~mL})$, and dried under powerful vacuum at $90{ }^{\circ} \mathrm{C}$ to give $[\mathrm{TMEDSA}][\mathrm{Cl}]_{2}{ }^{24}$ Then, trifluoroacetic acid $(10 \mathrm{mmol}, 1.140$ g) was added dropwise to [TMEDSA $][\mathrm{Cl}]_{2}(5 \mathrm{mmol}, 1.746 \mathrm{~g})$ over a period of $3 \mathrm{~min}$ at room temperature under pressure of nitrogen gas (to remove $\mathrm{HCl}$ produced during the reaction). The resulting mixture was stirred for $10 \mathrm{~h}$ at room temperature, and 2 hours at $60^{\circ} \mathrm{C}$ under a continuous flow of nitrogen gas to give $[$ TMEDSA $][\text { TFA }]_{2}$ as a viscous pale yellow liquid. ${ }^{1} \mathrm{H}$ NMR $\left(500 \mathrm{MHz}, \mathrm{DMSO}-\mathrm{d}_{6}\right): \delta / \mathrm{ppm}$ 2.99 (s, 12H,), 3.66 (s, 4H), 9.85 (br., 2H); ${ }^{13} \mathrm{C} \mathrm{NMR} \mathrm{(125.7} \mathrm{MHz,}$ DMSO-d $\left.{ }_{6}\right): \delta / p p m ~ 43.9,51.7,116.0(\mathrm{q}), 159.5(\mathrm{q}) ;{ }^{19} \mathrm{~F}$ NMR $(235$ MHz, DMSO-d $\left.{ }_{6}\right)$ : $\delta / p p m-70.57$ ppm; MS: m/z $504\left(\mathrm{M}^{+}\right), 505\left(\mathrm{M}^{+}+1\right)$.

General procedure for the production of 1,8-dioxo-9,10-diaryldecahydroacridines

A mixture of dimedone $(2 \mathrm{mmol})$, aldehyde $(1 \mathrm{mmol})$, amine $(1 \mathrm{mmol})$ and $\left[\right.$ TMEDSA] $[\text { TFA }]_{2}(0.1 \mathrm{mmol}, 0.051 \mathrm{~g})$ in absolute ethanol $(5 \mathrm{~mL})$ was stirred under reflux conditions. Completing the reaction was monitored by TLC. After completion of the reaction, the solvent was evaporated, and the obtained precipitate was recrystallized from hot ethanol $(95 \%)$ to give the pure 1,8-dioxo-9,10-diaryl-decahydroacridine.

\section{Selected spectroscopic data of the 1,8-dioxo-9,10-diaryl- decahydroacridines}

Compound 1e: ${ }^{1} \mathrm{H}$ NMR (500 MHz, DMSO- $\mathrm{d}_{6}$ ): $\delta / \mathrm{ppm} 0.80(\mathrm{~s}$, $6 \mathrm{H}), 0.96(\mathrm{~s}, 6 \mathrm{H}), 1.84(\mathrm{~d}, J=17.5 \mathrm{~Hz}, 2 \mathrm{H}), 2.07$ (d, $J=16.0 \mathrm{~Hz}$, $2 \mathrm{H}), 2.23-2.28(\mathrm{~m}, 4 \mathrm{H}), 2.59(\mathrm{~s}, 3 \mathrm{H}), 5.02(\mathrm{~s}, 1 \mathrm{H}), 6.70(\mathrm{~d}, J=8.0$ $\mathrm{Hz}, 2 \mathrm{H}), 7.16(\mathrm{~d}, J=8.0 \mathrm{~Hz}, 2 \mathrm{H}), 7.33(\mathrm{~m}, 2 \mathrm{H}), 7.48(\mathrm{~d}, J=7.5 \mathrm{~Hz}$, 2H), 9.15 (s, 1H); ${ }^{13} \mathrm{C}$ NMR (125.7 MHz, DMSO-d ${ }_{6}$ ): $\delta / p p m ~ 20.8$, 26.1, 29.4, 30.6, 32.0, 41.0, 49.7, 113.3, 113.4, 114.6, 128.4, 130.5, 136.0, 137.1, 138.8, 150.1, 155.3, 195.1.

Compound 1f: ${ }^{1} \mathrm{H}$ NMR $\left(500 \mathrm{MHz}, \mathrm{DMSO}-\mathrm{d}_{6}\right): \delta / \mathrm{ppm} 0.83(\mathrm{~s}$, $6 \mathrm{H}), 0.98(\mathrm{~s}, 6 \mathrm{H}), 1.85(\mathrm{~d}, J=17.5 \mathrm{~Hz}, 2 \mathrm{H}), 2.10(\mathrm{~d}, J=16.1 \mathrm{~Hz}$, 2H), 2.21-2.27 (m, 4H), $2.56(\mathrm{~s}, 3 \mathrm{H}), 5.17(\mathrm{~s}, 1 \mathrm{H}), 7.29(\mathrm{~m}, \mathrm{H})$, 7.39-7.47 (m, 3H), $7.96(\mathrm{~m}, 2 \mathrm{H}), 8.22(\mathrm{~m}, 1 \mathrm{H}) ;{ }^{13} \mathrm{C}$ NMR $(125.7$ MHz, DMSO- $\left.\mathrm{d}_{6}\right): \delta /$ ppm 21.3, 26.9, 30.0, 32.2, 32.9, 41.7, 49.3, $113.9,122.0,122.9,128.8,129.9,130.6,132.1,134.8,136.4,141.0$, 147.9, 151.3, 195.4.

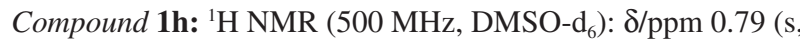
$6 \mathrm{H}), 0.95(\mathrm{~s}, 6 \mathrm{H}), 1.85(\mathrm{~d}, J=17.0 \mathrm{~Hz}, 2 \mathrm{H}), 2.08(\mathrm{~d}, J=16.0 \mathrm{~Hz}$, 2H), 2.25-2.29 (m, 4H), $2.58(\mathrm{~s}, 3 \mathrm{H}), 5.10(\mathrm{~s}, 1 \mathrm{H}), 7.30-7.45(\mathrm{~m}, 6 \mathrm{H})$, 7.49 (d, $J=7.0 \mathrm{~Hz}, 2 \mathrm{H}) ;{ }^{13} \mathrm{C} \mathrm{NMR}\left(125.7 \mathrm{MHz}\right.$, DMSO-d $\left.{ }_{6}\right): \delta / \mathrm{ppm}$ 20.8, 26.5, 28.6, 29.3, 32.0, 41.0, 49.5, 112.5, 114.0, 127.9, 129.4, $130.7,135.8,139.0,143.3,145.3,150.8,195.1 \mathrm{ppm}$.

\section{RESULTS AND DISCUSSION}

\section{Production and characterization of [TMEDSA] $][\text { TFA }]_{2}$}

Initially, we prepared $N, N, N$ ', $N$ '-tetramethylethylene-diaminium$N, N$ '-disulfonic acid trifluoroacetate by the reaction of chlorosulfonic acid (2 eq.) with $N, N, N^{\prime}, N^{\prime}$-tetramethylethylene-diamine (1 eq.), and then with trifluoroacetic acid (2 eq.) (Scheme 1).

Characterization of the ionic liquid was carried out by analyzing its ${ }^{1} \mathrm{H}$ NMR, ${ }^{13} \mathrm{C}$ NMR, ${ }^{19} \mathrm{~F}$ NMR, mass, thermogravimetry (TG) and DSC (differential scanning calorimetry) data.

The ${ }^{1} \mathrm{H}$ NMR spectrum of [TMEDSA] $[\mathrm{TFA}]_{2}$ (Figure 1) displayed 3 peaks: 2.98 (s, 12H), 3.65 (s, $4 \mathrm{H})$ and 9.84 (br., $2 \mathrm{H}) \mathrm{ppm}$. In this Figure, the corresponded hydrogens to each peak have been indicated.

In the ${ }^{13} \mathrm{C}$ NMR spectrum (Figure 2), 4 peaks were observed [43.9, $51.7,116.0$ (quartet) and 159.5 (quartet) ppm]. The related carbons to each peak are shown in Figure 2.

The ${ }^{19} \mathrm{~F} \mathrm{NMR}$ spectrum of [TMEDSA][TFA $]_{2}$ (Figure 3 ) showed a singlet peak at $-70.57 \mathrm{ppm}$ which corresponds to 6 fluorine atoms of the two $\mathrm{CF}_{3}$ groups.

In the mass spectrum of [TMEDSA][TFA $]_{2}$ (Figure 4), the peaks observed at $m / z 504$ and 505 are related to the molecular mass $\left(\mathrm{M}^{+}\right)$ and $\left(\mathrm{M}^{+}+1\right)$, respectively.

Thermogravimetric analysis (TGA) of $\left[\right.$ TMEDSA] $[\text { TFA }]_{2}$ was also investigated. The relevant diagrams are illustrated in Figures 5 and 6. The TG (thermogravimetry), DTG (differential thermogravimetry) and DTA (differential thermal analysis) showed weight loss in four steps at about: (i) 100-145, (ii) 150-235, (iii) 250-305 (main weight loss), and (iv) $305-500{ }^{\circ} \mathrm{C}$.

The DSC (differential scanning calorimetry) curve of [TMEDSA] $[\mathrm{TFA}]_{2}$ was studied at the temperature range 25 to $300{ }^{\circ} \mathrm{C}$ at scan rate up to $10{ }^{\circ} \mathrm{C} / \mathrm{min}$ (Figure 7). As it can be seen in the Figure, decomposition of the room temperature ionic liquid was achieved about 143,168 and $300{ }^{\circ} \mathrm{C}$; these are in accordance with first to third weight loss which observed in TGA diagrams.

\section{Examining catalytic activity of [TMEDSA][TFA $]_{2}$ for the synthesis 1,8-dioxo-9,10-diaryl-decahydroacridines}

Catalytic performance of the ionic liquid was tested for the production of 1,8-dioxo-9,10-diaryl-decahydroacridines. For optimizing the reaction conditions, the condensation of dimedone (2 mmol) with 4-chlorobenzaldehyde $(1 \mathrm{mmol})$ and $p$-toluidine (1.2 mmol) was chosen as a model reaction (Scheme 2), and studied in the presence of different mol\% of [TMEDSA][TFA $]_{2}$ in several solvents (and under solvent-free conditions) at range of 60 to $78^{\circ} \mathrm{C}$ (boiling point of $\mathrm{EtOH}$ ); the related results are briefed in Table 1. As the data of this Table indicate, when $10 \mathrm{~mol} \%$ of the catalyst was utilized in $\mathrm{EtOH}$, the best results were obtained (entry 3 ).

To indicate effectuality and generality of [TMEDSA][TFA $]_{2}$ for the production of 1,8-dioxo-9,10-diaryl-decahydroacridines, after that optimization of the reaction conditions was achieved, dimedone was reacted with diverse arylaldehydes and amines ( $p$-toluidine and aniline); the results are illustrated in Table 2. According to these results, all reactions proceeded effectively, and 1,8-dioxo-9,10-diaryldecahydroacridines were produced in high to excellent yields using both electron-rich and electron-poor arylaldehydes. In all cases, the acridine derivatives were the sole products, and no by-products were

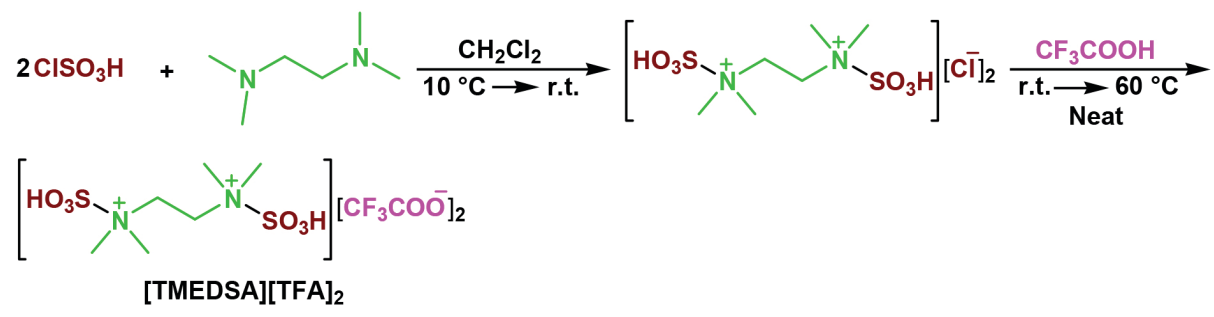

Scheme 1. The preparation of [TMEDSA][TFA $]_{2}$ 


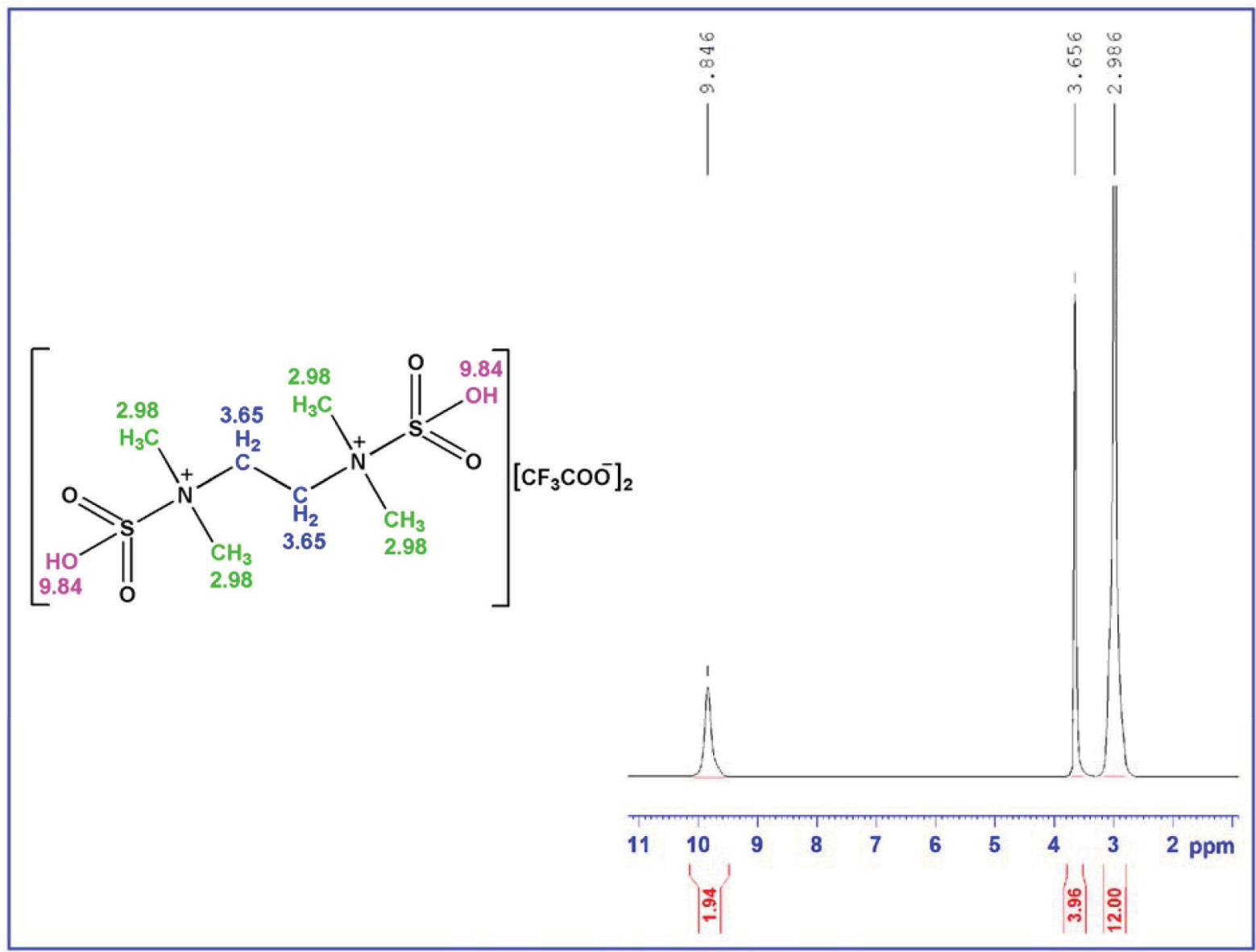

Figure 1. The ${ }^{l} H$ NMR spectrum of [TMEDSA][TFA $]_{2}$

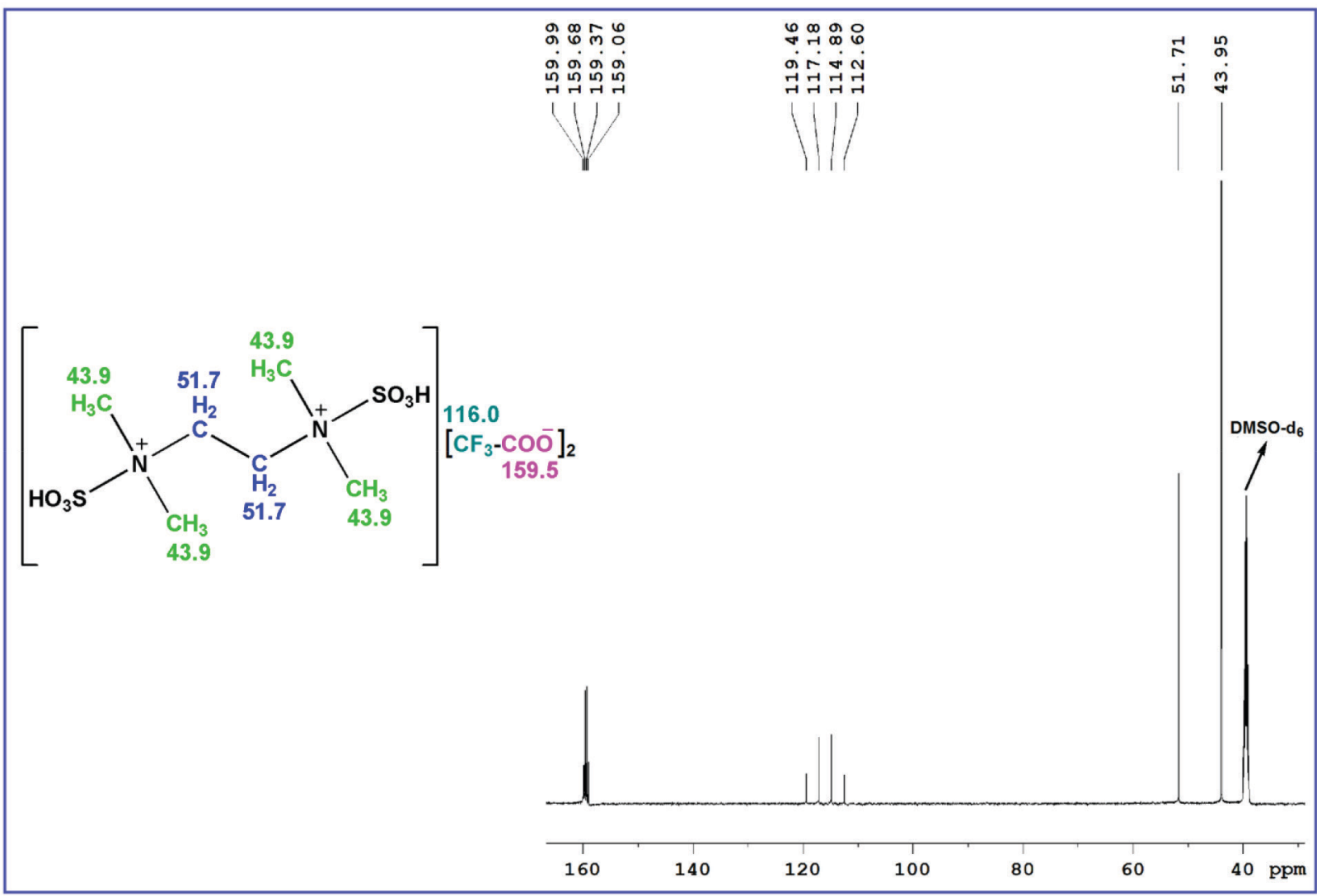

Figure 2. The ${ }^{13} \mathrm{C} N M R$ spectrum of the catalyst 


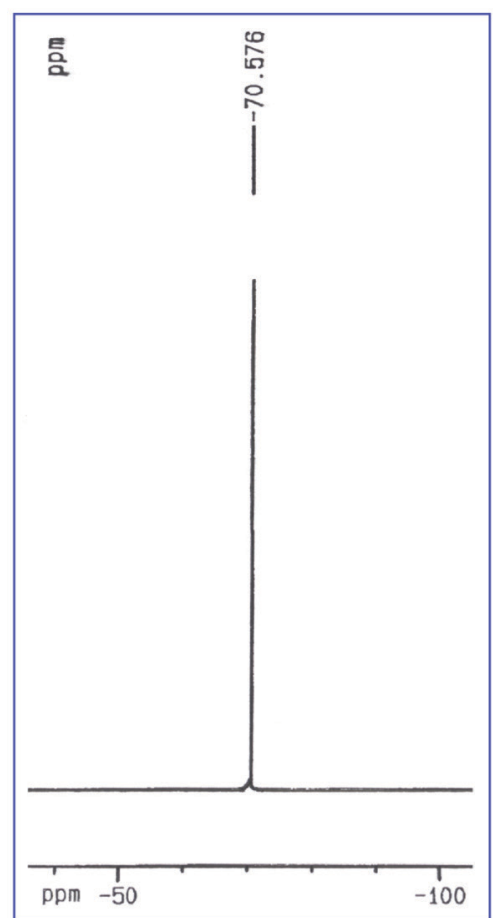

Figure 3. The ${ }^{19} \mathrm{~F}$ NMR spectrum of [TMEDSA][TFA $]_{2}$

observed. Thus, $[$ TMEDSA $][\text { TFA }]_{2}$ was highly effective and general catalyst for the synthesis.

Our novel ionic liquid (IL) is a dual-functional catalyst, since it has both acidic and basic sites $\left(\mathrm{SO}_{3} \mathrm{H}\right.$ group is acidic, and trifluoroacetate is basic); in addition, there are two sites of each in the catalyst (Figure 8 ). Therefore, [TMEDSA][TFA $]_{2}$ can especially apply as a highly effectual and general catalyst for reactions which

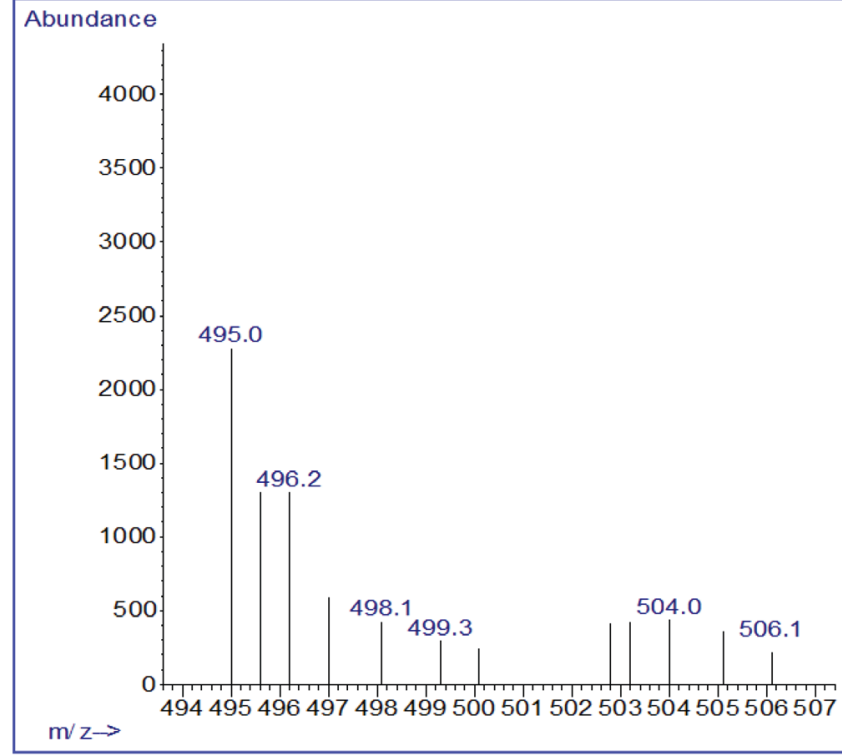

Figure 4. The mass spectrum of [TMEDSA][TFA $]_{2}$

need to both acidic and basic catalysts simultaneously; e.g. the preparation of 1,8-dioxo-9,10-diaryl-decahydroacridines; this matter has been illustrated in the reaction mechanism (Scheme 3). Moreover, two acidic and two basic sites of [TMEDSA] $[\mathrm{TFA}]_{2}$ can simultaneously catalyze the reaction. In the reaction, the acidic sites can activate the carbonyl groups (electrophiles) for nucleophilic attack to accelerate steps $2,6,8$ and 11 ; these sites can also accelerate removing $\mathrm{H}_{2} \mathrm{O}$ from the intermediates by hydrogen bonding with hydroxyl groups (steps 4, 9 and 12). The trifuoroacetate anions can speed up steps 2, 6, 8 and 11 by activating the nucleophiles via assistance to attracting a proton; the basic sites

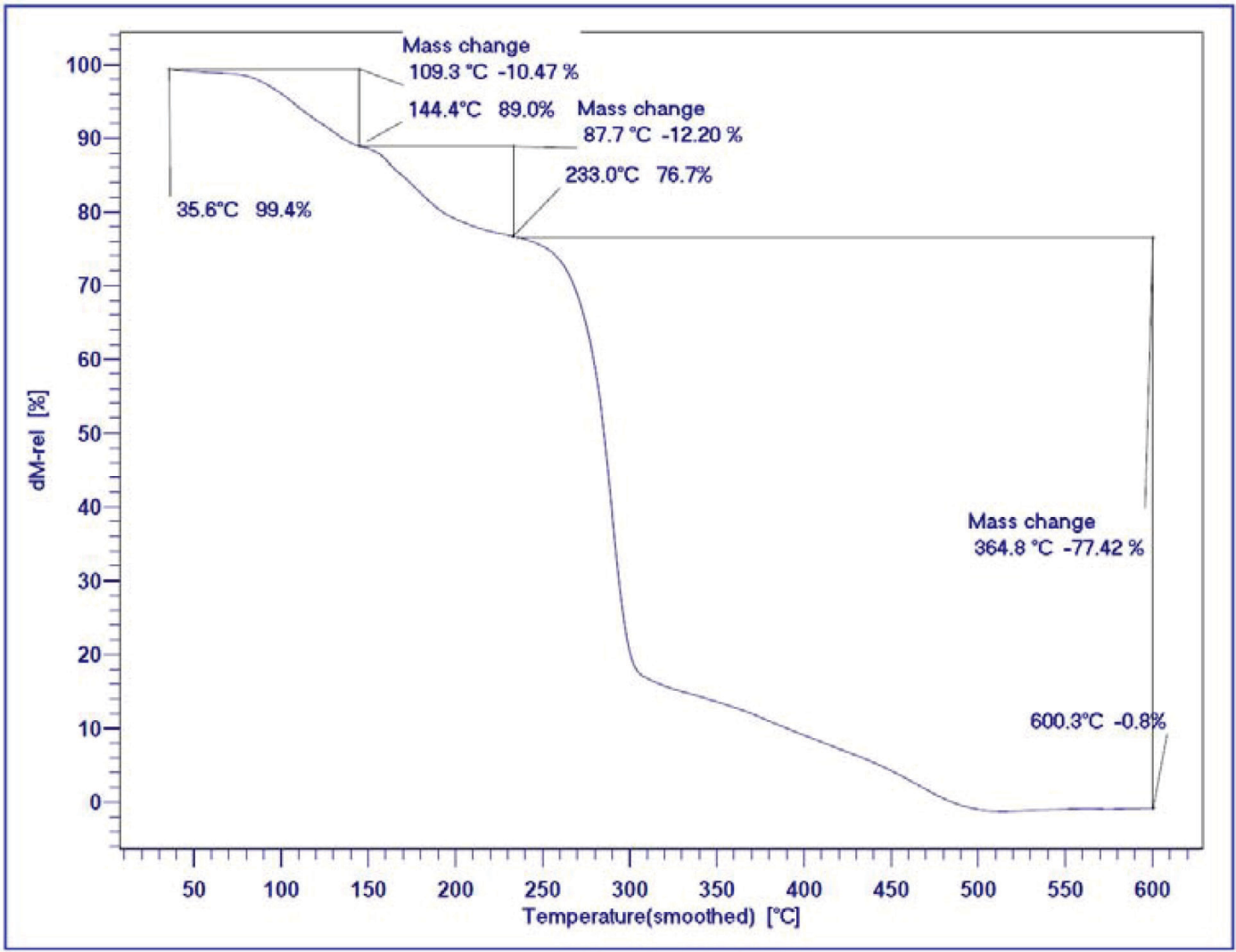

Figure 5. The TG diagram of [TMEDSA][TFA $]_{2}$ 


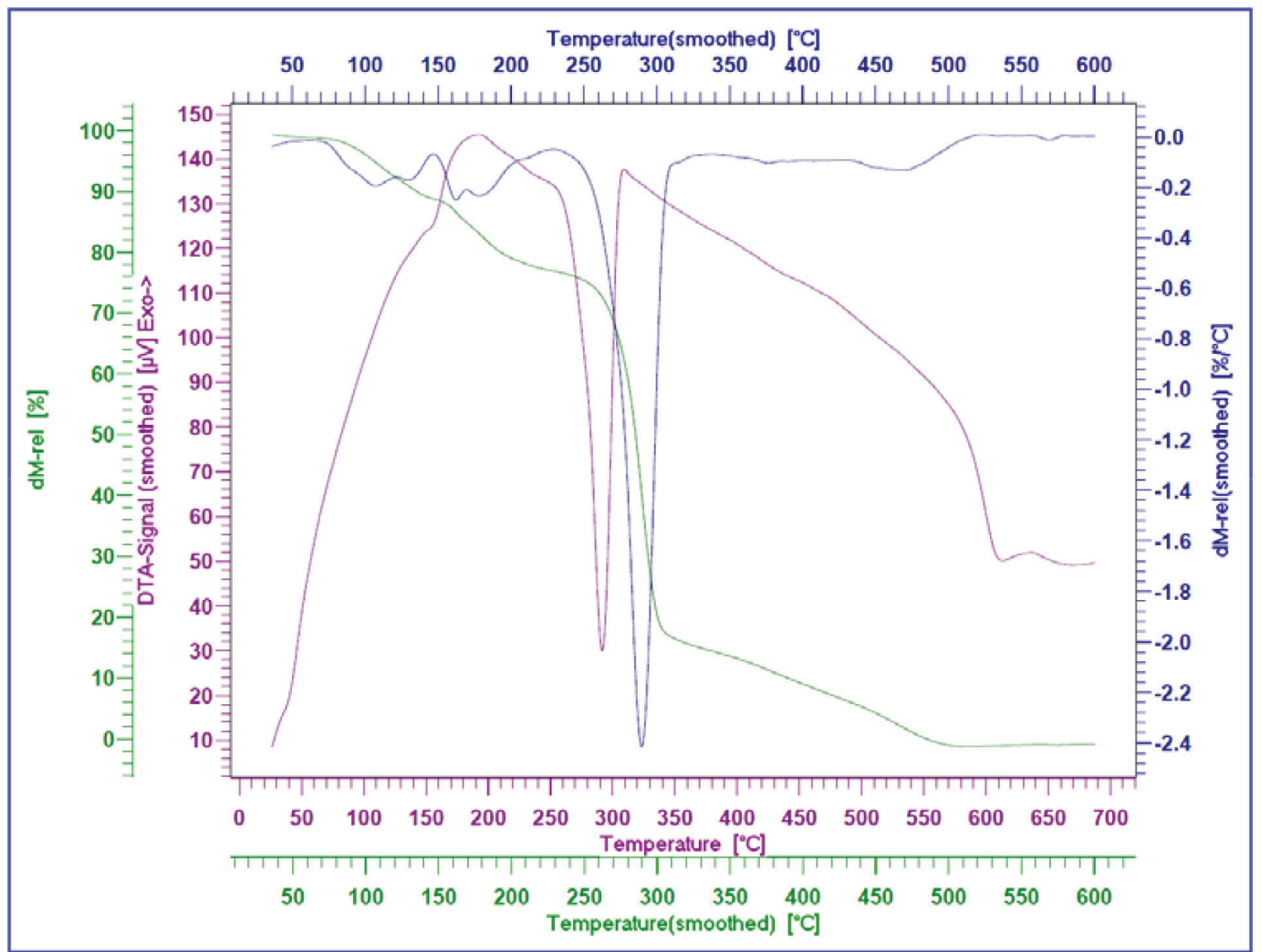

Figure 6. The TG, DTG and DTA diagrams of the catalyst

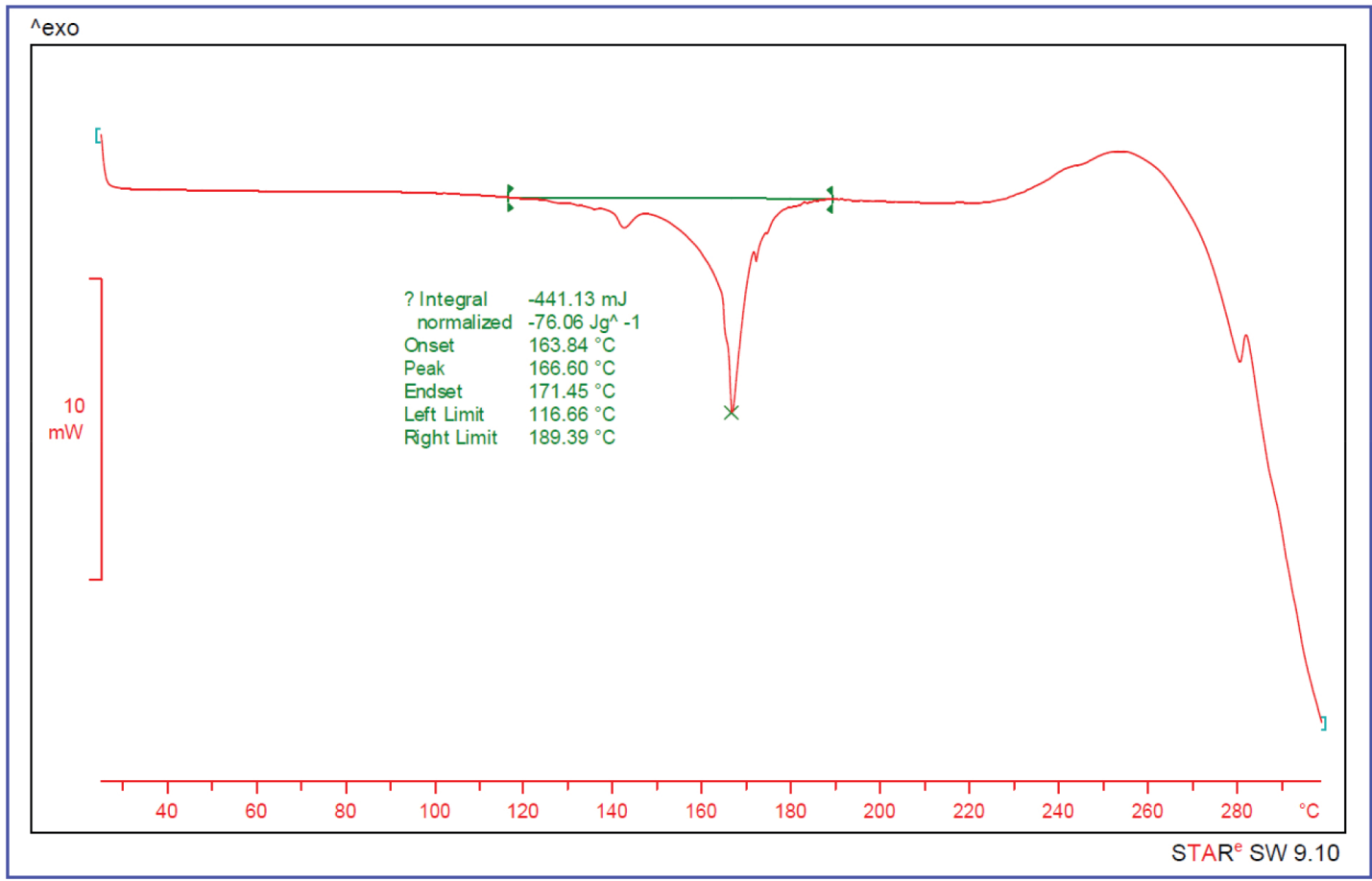

Figure 7. The DSC curve of [TMEDSA][TFA $]_{2}$

also accelerate removal of $\mathrm{H}_{2} \mathrm{O}$ from the intermediates by assistance to abstracting a proton (steps 4, 9 and 12). In fact, high efficacy of [TMEDSA][TFA $]_{2}$ can be attributed dual-functionality, having two acidic and two basic sites, ability to activate the electrophiles and the nucleophiles and accelerating all steps of the reaction mechanism.
In another study for illustrating effectiveness of the catalyst, the results and reaction conditions of [TMEDSA][TFA $]_{2}$ were compared with those in the reported catalysts; the results are briefed in Table 3. As the Table shows, [TMEDSA][TFA $]_{2}$ gave better results (in terms of yield, temperature and/or solvent and/or time) with respect to the other catalysts. 


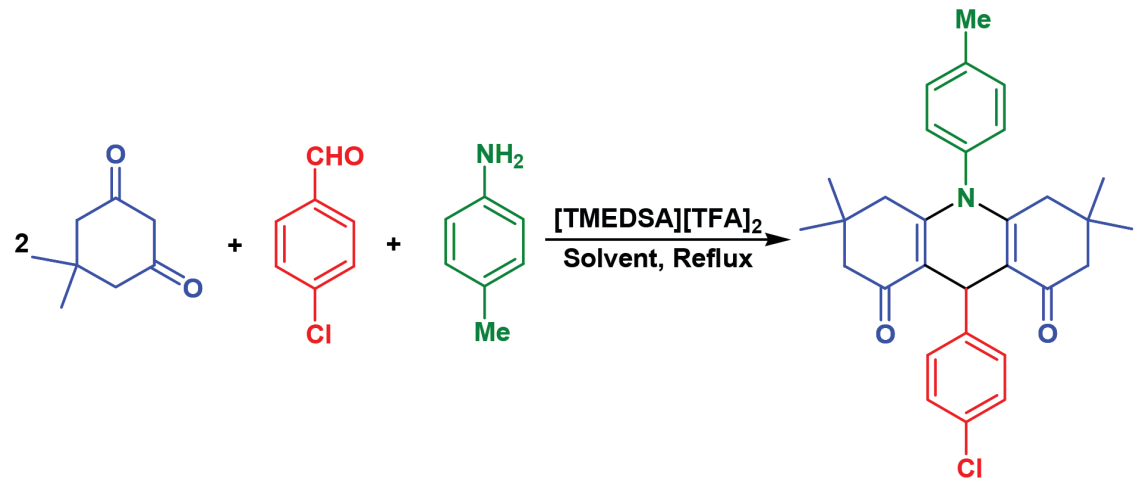

Scheme 2. The model reaction for the synthesis of 1,8-dioxo-9,10-diaryl-decahydroacridines

Table 1. Influence of the catalyst quantity, solvent and temperature on the model reaction

\begin{tabular}{lccccc}
\hline Entry & $\begin{array}{c}\text { Mol\% of } \\
{[\text { TMEDSA][TFA }]_{2}}\end{array}$ & Solvent & $\begin{array}{c}\text { Temp. } \\
\left({ }^{\circ} \mathrm{C}\right)\end{array}$ & $\begin{array}{c}\text { Time } \\
(\mathrm{h})\end{array}$ & $\begin{array}{c}\text { Yield }^{\mathrm{a}} \\
(\%)\end{array}$ \\
\hline 1 & 5 & EtOH & Reflux & 8 & 87 \\
2 & 7 & $\mathrm{EtOH}$ & Reflux & 5 & 92 \\
3 & 10 & $\mathrm{EtOH}$ & Reflux & 3 & 95 \\
4 & 13 & $\mathrm{EtOH}$ & Reflux & 3 & 95 \\
5 & 10 & $\mathrm{MeOH}$ & Reflux & 4 & 93 \\
6 & 10 & $\mathrm{Solvent-free}$ & 78 & 2 & 28 \\
7 & 10 & $\mathrm{MeCN}$ & 78 & 3 & 94 \\
8 & 10 & EtOAc & Reflux & 3 & 93 \\
9 & 10 & $\mathrm{THF}$ & Reflux & 4 & 90 \\
10 & 10 & $\mathrm{CH} \mathrm{H}_{2}$ & Reflux & 7 & 85 \\
11 & 10 & $1,4-\mathrm{Dioxane}$ & 78 & 3 & 92 \\
12 & 10 & $\mathrm{H}_{2} \mathrm{O}$ & 78 & 12 & 21 \\
13 & 10 & $\mathrm{EtOH}^{2}$ & 60 & 5 & 70 \\
14 & 10 & $\mathrm{EtOH}^{2}$ & 70 & 4 & 78 \\
\hline
\end{tabular}

Isolated yield.

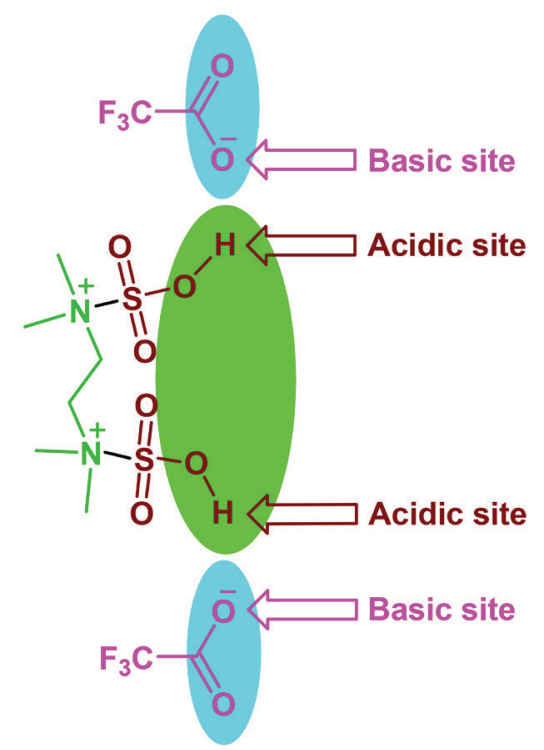

Figure 8 . The acidic and basic sites of [TMEDSA][TFA $]_{2}$

Table 2. The synthesis 1,8-dioxo-9,10-diaryl-decahydroacridines catalyzed by [TMEDSA][TFA] $]_{2}$

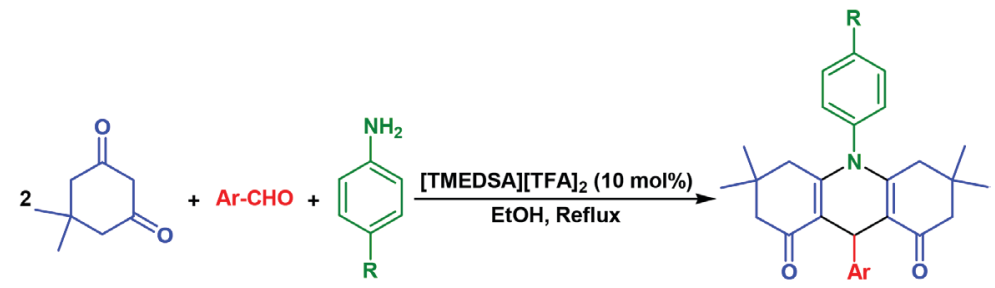

\begin{tabular}{lccccc}
\hline Product & $\mathrm{Ar}$ & $\mathrm{R}$ & Time $(\mathrm{h})$ & Yield $^{\mathrm{a}}(\%)$ & M.p. $\left({ }^{\circ} \mathrm{C}\right)[\mathrm{Lit}]$. \\
\hline $1 \mathrm{a}$ & $\mathrm{C}_{6} \mathrm{H}_{5}$ & $\mathrm{Me}$ & 93 & $257-259(260-262)^{10}$ \\
$1 \mathrm{~b}$ & $4-\mathrm{MeC}_{6} \mathrm{H}_{4}$ & $\mathrm{Me}$ & 4 & 93 & $297-299(296-297)^{28}$ \\
$1 \mathrm{c}$ & $4-\mathrm{MeOC}_{6} \mathrm{H}_{4}$ & $\mathrm{Me}$ & 3 & 91 & $279-281(281-283)^{10}$ \\
$1 \mathrm{~d}$ & $3,4,5-\left(\mathrm{MeO}_{3} \mathrm{C}_{6} \mathrm{H}_{2}\right.$ & $\mathrm{Me}$ & 3 & 87 & $222-224(224-226)^{29}$ \\
$1 \mathrm{e}$ & $4-\mathrm{HOC}_{6} \mathrm{H}_{4}$ & $\mathrm{Me}$ & 7 & 90 & $350-352(352-354)^{16}$ \\
$1 \mathrm{f}$ & $3-\mathrm{O}_{2} \mathrm{NC}_{6} \mathrm{H}_{4}$ & $\mathrm{Me}$ & 5 & 94 & $283-285(283-284)^{10}$ \\
$1 \mathrm{~g}$ & $4-\mathrm{O}_{2} \mathrm{NC}_{6} \mathrm{H}_{4}$ & $\mathrm{Me}$ & 3 & 95 & $272-274(272-274)^{12}$ \\
$1 \mathrm{~h}$ & $4-\mathrm{ClC}_{6} \mathrm{H}_{4}$ & $\mathrm{Me}$ & 3 & 95 & $268-270(269-271)^{10}$ \\
$1 \mathrm{i}$ & $2-\mathrm{ClC}_{6} \mathrm{H}_{4}$ & $\mathrm{Me}$ & 3 & 88 & $288-290(285-287)^{30}$ \\
$1 \mathrm{j}$ & $4-\mathrm{BrC}_{6} \mathrm{H}_{4}$ & $\mathrm{Me}$ & 3 & 91 & $267-269(270-272)^{28}$ \\
$1 \mathrm{k}$ & $\mathrm{C}_{6} \mathrm{H}_{5}$ & $\mathrm{H}$ & 3 & 92 & $253-255(255-256)^{16}$ \\
11 & $4-\mathrm{MeOC}_{6} \mathrm{H}_{4}$ & $\mathrm{H}$ & 3 & 89 & $217-219(219-222)^{16}$ \\
\hline
\end{tabular}

${ }^{\mathrm{a}}$ Isolated yield. 

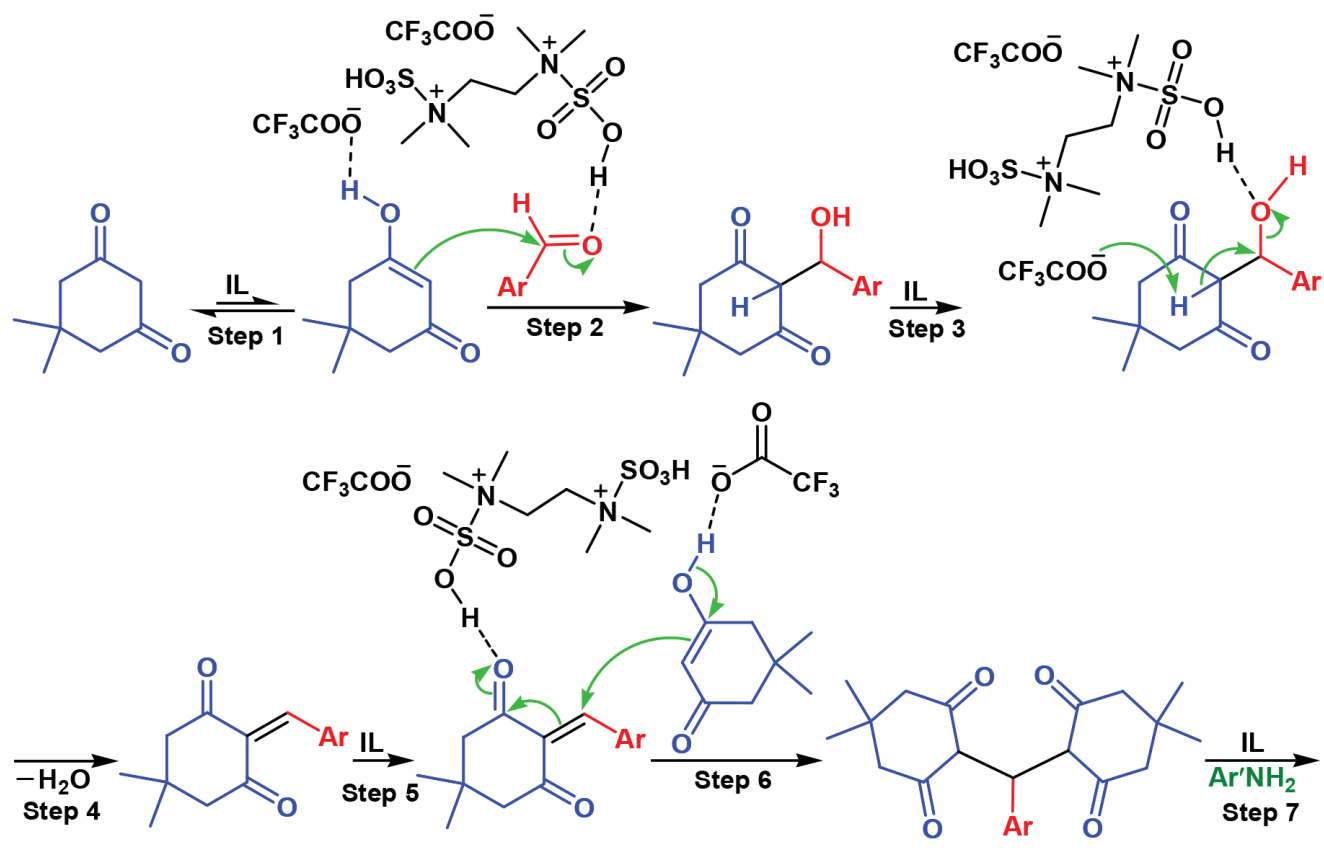

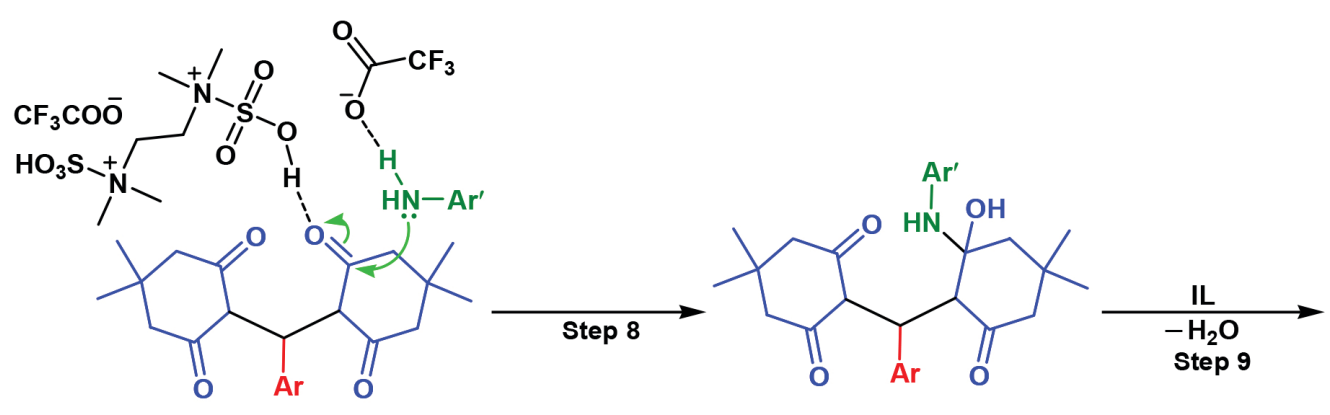

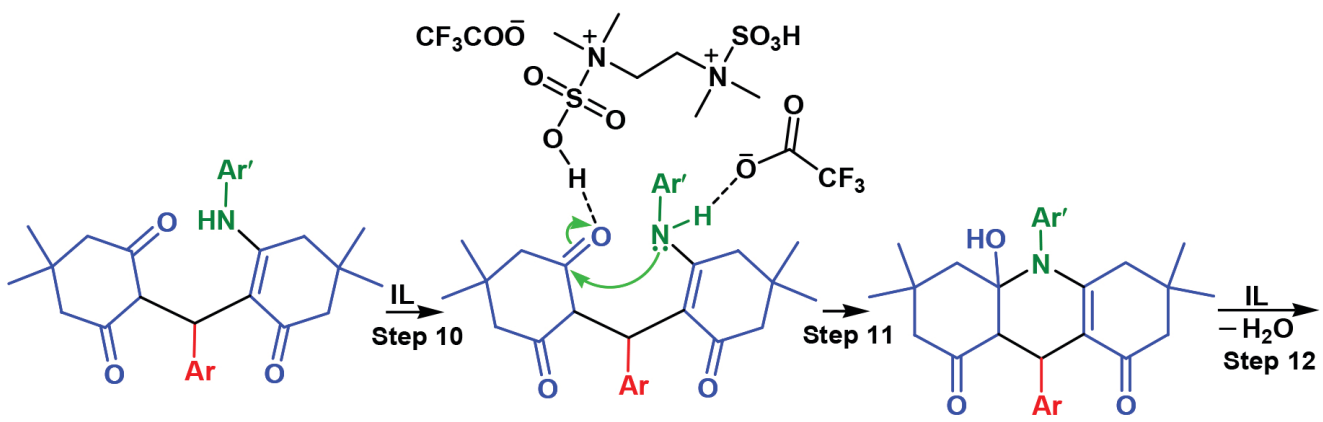<smiles>CC1(C)CC(=O)C2=C(C1)N([Ga])C1=C(C(=O)CC(C)(C)C1)C2Br</smiles>

Scheme 3. The proposed mechanism

\section{CONCLUSIONS}

In summary, we have introduced $N, N, N^{\prime}, N^{\prime}$-tetramethylethylenediaminium- $N, N^{\prime}$-disulfonic acid trifluoroacetate as a novel and homogeneous catalyst for the production of 1,8-dioxo-9,10-diaryldecahydroacridines. The benefits for the presented protocol are generality, efficacy, high yields, relatively short reaction times, clean reaction profile, simple experimental procedure, purification of compounds by non-chromatography method (crystallization only), wide range of substrate applicability, low cost, easy preparation of the catalyst from available reactants, and dual-functionality of the catalyst. Although [TMEDSA][TFA $]_{2}$ was not recyclable; however, its utilization as catalyst for organic transformations is economic, because of possessing many advantages which mentioned above.

\section{ACKNOWLEDGEMENTS}

We thank Research Council of Payame Noor University for providing necessary research facilities and the financial support of this work. 
Table 3. Comparison of the results and reaction conditions of [TMEDSA][TFA $]_{2}$ with the reported catalysts

\begin{tabular}{|c|c|c|c|c|}
\hline Catalyst & Conditions & Time range & Yield range $(\%)$ & Ref. \\
\hline$[\mathrm{TMEDSA}][\mathrm{TFA}]_{2}$ & EtOH, Reflux & $3-7 \mathrm{~h}$ & $87-95$ & This work \\
\hline Nano- $\mathrm{ZrO}_{2}-\mathrm{SO}_{3} \mathrm{H}$ & Solvent-free, $100{ }^{\circ} \mathrm{C}$ & $35-65 \min$ & $84-94$ & 8 \\
\hline $\mathrm{Fe}_{3} \mathrm{O}_{4} @ \mathrm{SiO}_{2}-\mathrm{MoO}_{3} \mathrm{H}$ nanoparticles & Solvent-free, $90^{\circ} \mathrm{C}$ & $20-55 \mathrm{~min}$ & $88-94$ & 9 \\
\hline Imidazolium salts containing perfluoroalkyl tails & EtOH, Reflux & $4 \mathrm{~h}$ & $79-91$ & 10 \\
\hline Tungstophosphoric acid nanoparticles supported on polyamic acid & EtOH- $\mathrm{H}_{2} \mathrm{O}$, Reflux & $40-60 \mathrm{~min}$ & $50-92$ & 11 \\
\hline Nano- $\mathrm{Fe}_{3} \mathrm{O}_{4}$ & Solvent-free, $120^{\circ} \mathrm{C}$ & $10-50 \mathrm{~min}$ & $70-95$ & 12 \\
\hline$\beta$-Cyclodextrin & $\mathrm{H}_{2} \mathrm{O}$, Ultrasound, $80{ }^{\circ} \mathrm{C}$ & $61-81 \min$ & $72-94$ & 13 \\
\hline $\mathrm{Fe}_{2} \mathrm{O}_{3}-\mathrm{ZrO}_{2}$ & MeCN, Reflux & $3-5 \mathrm{~h}$ & $80-90$ & 14 \\
\hline Nano- $\mathrm{TiO}_{2}$ & Solvent-free, $75^{\circ} \mathrm{C}$ & $10-60 \mathrm{~min}$ & $70-90$ & 15 \\
\hline Sulfonated polyethylene glycol & $\mathrm{H}_{2} \mathrm{O}, 90{ }^{\circ} \mathrm{C}$ & $3-6 h$ & $73-89$ & 16 \\
\hline Sulfated zirconia & $\mathrm{EtOH}, 70^{\circ} \mathrm{C}$ & $8 \mathrm{~h}$ & $89-95$ & 31 \\
\hline $\begin{array}{l}\text { N-Propyl benzoguanamine sulfonic acid supported on magnetic } \\
\mathrm{Fe}_{3} \mathrm{O}_{4} \text { nanoparticles }\end{array}$ & $\mathrm{EtOH}-\mathrm{H}_{2} \mathrm{O}, 100^{\circ} \mathrm{C}$ & $15-20 \mathrm{~min}$ & $84-95$ & 32 \\
\hline Baker's yeast & MeCN, Ultrasound, r.t. & $2.9-4.3 \mathrm{~h}$ & $70-84$ & 33 \\
\hline $\mathrm{HCl}$ & DMF, $100{ }^{\circ} \mathrm{C}$ & $30-75 \mathrm{~min}$ & $61-90$ & 34 \\
\hline Cellulose sulfuric acid & MeCN, Reflux & $4-7 \mathrm{~h}$ & $40-85$ & 35 \\
\hline $\mathrm{NH}_{4} \mathrm{Cl}$ & Solvent-free, $120^{\circ} \mathrm{C}$ & $45-120 \mathrm{~min}$ & $84-91$ & 36 \\
\hline
\end{tabular}

\section{REFERENCES}

1. Gamega, S. A.; Spicer, J. A.; Atwell, G. J.; Finlay, G. J.; Baguley, B. C.; Deny, W. A.; J. Med. Chem. 1999, 42, 2383.

2. Ngadi, L.; Galy, A. M.; Galy, J. P.; Barbe, J.; Cremieux, A.; Chevalier, J.; Sharples, D.; Eur. J. Med. Chem. 1990, 25, 67.

3. Gallo, S.; Atifi, S.; Mohamoud, A.; Santelli-Rouvier, C.; Wolfart, K.; Molnar, J.; Barbe, J.; Eur. J. Med. Chem. 2003, 38, 19.

4. Wainwright, M. J.; J. Antimicrob. Chemother. 2001, 47, 1.

5. Antonini, I.; Polucci, P.; Kelland, L. R.; Menta, E.; Pescalli, N.; Martelli, S.; J. Med. Chem. 1999, 42, 2535.

6. Tu, Sh. J.; Miao, C.; Gao, Y.; Fang, F.; Zhuang, Q.; Feng, Y.; Shi, D.; Synlett 2004, 255.

7. Murugan, P.; Shanmugasundaram, P.; Ramakrishnan, V. T.; Venkatachalapathy, B.; Srividya, N.; Ramamurthy, P.; Gunasekaran, K.; Velmurugan, D.; J. Chem. Soc., Perkin Trans. 2 1998, 999.

8. Amoozadeh, A.; Rahmani, S.; Bitaraf, M.; Bolghan Abadi, F.; Tabrizian, E.; New J. Chem. 2016, 40, 770.

9. Kiani, M.; Mohammadipour, M.; RSC Adv. 2017, 7, 997.

10. Shen, W.; Wang, L.-M.; Tian, H.; Tang, J.; Yu, J.-J.; J. Fluorine Chem. 2009, 130, 522.

11. Nasr-Esfahani, M.; Rafiee, Z.; Kashi, H.; J. Iran. Chem. Soc. 2016, 13, 1449.

12. Ghasemzadeh, M. A.; Safaei-Ghomi, J.; Molaei, H.; C. R. Chim. 2012, 15,969 .

13. Chate, A. V.; Rathod, U. B.; Kshirsagar, J. S.; Gaikwad, P. A.; Mane, K. D.; Mahajan, P. S.; Nikam, M. D.; Gill, C. H.; Chin. J. Catal. 2016, 37, 146.

14. Pradhan, S.; Mishra, B. G.; RSC Adv. 2015, 5, 86179.

15. Khazaei, A.; Moosavi-Zare, A. R.; Mohammadi, Z.; Khakyzadeh, V.; Afsar, J.; J. Chin. Chem. Soc. 2016, 63, 165.

16. Hasaninejad, A.; Shekouhy, M.; Miar, M.; Firoozi, S.; Synth. React. Inorg. Nano-Met. Chem. 2016, 46, 151.

17. Rezayati, S.; Salehi, E.; Hajinasiri, R.; Afshari Sharif Abad, S.; C. R. Chim. 2017, 20, 554.

18. Mahato, S.; Santra, S.; Chatterjee, R.; Zyryanov, G. V.; Hajra, A.; Majee, A.; Green Chem. 2017, 19, 3282.
19. Rad-Moghadam, K.; Mousazadeh Hassani, S. A. R.; Toorchi Roudsari, S.; J. Mol. Liq. 2016, 218, 275.

20. Senapak, W.; Saeeng, R.; Jaratjaroonphong, J.; Kasemsuk, T.; Sirio, U.; Org. Biomol. Chem. 2016, 14, 1302.

21. Zolfigol, M. A.; Khazaei, A.; Moosavi-Zare, A. R.; Zare, A.; Kruger, H. G.; Asgari, Z.; Khakyzadeh, V.; Kazem-Rostami, M.; J. Org. Chem. 2012, 77, 3640 .

22. Zare, A.; Yousofi, T.; Moosavi-Zare, A. R.; RSC Adv. 2012, 2, 7988.

23. Zare, A.; Nasouri, Z.; J. Mol. Liq. 2016, 216, 364.

24. Zare, A.; Sharif, E.; Arghoon, A.; Ghasemi, M.; Dehghani, B.; AhmadZadeh, S.; Zarei, F.; Iran. J. Catal. 2017, 7, 233.

25. Rathi, A. K.; Gawande, M. B.; Zboril, R.; Varma, R. S.; Coord. Chem. Rev. 2015, 291, 68.

26. Asadi, B.; Landarani-Isfahani, A.; Mohammadpoor-Baltork, I.; Tangestaninejad, S.; Moghadam, M.; Mirkhani, V.; Amiri Rudbari, H.; Tetrahedron Lett. 2017, 58, 71 .

27. Moosavi-Zare, A. R.; Zolfigol, M. A.; Zarei, M.; Zare, A.; Afsar, J.; Appl. Catal., A 2015, 505, 224.

28. Wang, X.-S.; Zhang, M.-M.; Jiang, H.; Shi, D.-Q.; Tu, S.-J.; Wei, X.-Y.; Zong, Z.-M.; Synthesis 2006, 4187.

29. Soliman, H. A.; Mubarak, A. Y.; El-Mekabati, A.; Elmorsy, S. S.; Chem. Sci. Trans. 2014, 3, 819.

30. Jin, T. S.; Zhang, J. S.; Guo, T. T.; Wang, A. Q.; Li, T. S.; Synthesis 2004, 2001.

31. Kahandal, S. S.; Burange, A. S.; Kale, S. R.; Prinsen, P.; Luque, R.; Jayaram, R. V.; Catal. Commun. 2017, 97, 138.

32. Gholami Dehbalaei, M.; Foroughifar, N.; Pasdar, H.; Khajeh-Amiri, A.; New J. Chem. 2018, 42, 327.

33. Chate, A. V.; Sukale, S. B.; Ugale, R. S.; Gill, C. H.; Synth. Commun. 2017, 47, 409 .

34. Saljooghi, A. S.; Khabazzadeh, H.; Khaleghi, M.; J. Iran. Chem. Soc. 2017, 14, 727.

35. Rajack, A.; Yuvarajua, K.; Praveena, C.; Murthy, Y. L. N.; J. Mol. Catal. A: Chem. 2013, 370, 197.

36. Banerjee, B.; Brahmachari, G.; J. Chem. Res. 2014, 38, 701. 